Hydrology and Earth System Sciences, 9, 139-155, 2005

www.copernicus.org/EGU/hess/hess/9/139/

SRef-ID: 1607-7938/hess/2005-9-139

European Geosciences Union

\title{
Using stable isotope tracers to assess hydrological flow paths, residence times and landscape influences in a nested mesoscale catchment
}

\author{
P. Rodgers ${ }^{1}{ }^{*}$, C. Soulsby ${ }^{1}$, S. Waldron ${ }^{2}$, and D.Tetzlaff ${ }^{1}$ \\ ${ }^{1}$ Department of Geography and Environment, University of Aberdeen, Elphinstone Road, Aberdeen, AB24 3UF, UK \\ ${ }^{2}$ Scottish Universities Environmental Research Centre, Scottish Enterprise Technology Park, East Kilbride, Glasgow, G75 \\ OQF, UK \\ "now at: SEPA, Rivers House, Irongray Road, Dumfries, DG2 OJE, UK
}

Received: 22 December 2004 - Published in Hydrology and Earth System Sciences Discussions: 13 January 2005

Revised: 10 June 2005 - Accepted: 11 July 2005 - Published: 22 July 2005

\begin{abstract}
O}$ measurements in precipitation and stream waters were used to investigate hydrological flow paths and residence times at nested spatial scales in the mesoscale $\left(233 \mathrm{~km}^{2}\right)$ River Feugh catchment in the northeast of Scotland over the 2001-2002 hydrological year. Precipitation $\delta^{18} \mathrm{O}$ exhibited strong seasonal variation, which although significantly damped within the catchment, was reflected in stream water at six sampling sites. This allowed $\delta^{18} \mathrm{O}$ variations to be used to infer the relative influence of soil-derived storm flows with a seasonally variable isotopic signature, and groundwater of apparently more constant isotopic composition. Periodic regression analysis was then used to examine the sub-catchment difference using an exponential flow model to provide indicative estimates of mean stream water residence times, which varied between approximately 3 and 14 months. This showed that the effects of increasing scale on estimated mean stream water residence time was minimal beyond that of the smallest (ca. $1 \mathrm{~km}^{2}$ ) headwater catchment scale. Instead, the interaction of catchment soil cover and topography appeared to be the dominant controlling influence. Where sub-catchments had extensive peat coverage, responsive hydrological pathways produced seasonally variable $\delta^{18} \mathrm{O}$ signatures in runoff with short mean residence times (ca. 3 months). In contrast, areas dominated by steeper slopes, more freely draining soils and larger groundwater storage in shallow valley-bottom aquifers, deeper flow paths allow for more effective mixing and damping of $\delta^{18} \mathrm{O}$ indicating longer residence times ( $>12$ months). These insights from $\delta^{18} \mathrm{O}$ measurements extend the hydrological understanding of the Feugh catchment gained from previous

Correspondence to: $\mathrm{P}$. Rodgers

(paul.rodgers@sepa.org.uk)
\end{abstract}

geochemical tracer studies, and demonstrate the utility of isotope tracers in investigating the interaction of hydrological processes and catchment characteristics at larger spatial scales.

\section{Introduction}

Over the past two decades, interpretation of changes in the stable oxygen $\left({ }^{18} \mathrm{O} /{ }^{16} \mathrm{O}\right)$ isotopic signatures of catchment waters have provided insights as tracers for identifying hydrological sources and flow paths under different flow conditions and estimating mean catchment residence times (Sklash, 1990; Genereux and Hooper, 1998; Burns, 2002). To date, most studies have focused on storm event sampling in relatively small $\left(<10 \mathrm{~km}^{2}\right)$ catchments (Buttle, 1994). However, the use of isotope tracers to upscale flow path understanding in mesoscale (ca. $10^{2}-10^{3} \mathrm{~km}^{2}$ ) catchments over longer timescale has been scarce (e.g. Sklash et al., 1976; Turner and Barnes, 1998; Frederickson and Criss, 1999; Uhlenbrook et al., 2002). Moreover, investigations of the influence of catchment scale on the mean residence time of runoff have generally been restricted to relatively small catchments (Brown et al., 1999; McDonnell et al., 1999; McGlynn et al., 2003). This reflects the logistical difficulties of sampling in larger catchments, the potential loss of isotopic tracer resolution at larger spatial and temporal scales and the expense of isotope analysis (Buttle, 1998; Kendall and Coplen, 2001). Nevertheless, where the relationship between catchment size and mean residence time has been examined, many field and theoretical studied have shown that superficial assumptions that residence time increases with

(C) 2005 Author(s). This work is licensed under a Creative Commons License. 
catchment size are unfounded (Haitjema, 1995; McGuire et al., 2005). However, given the paucity of such studies it is clear that the relationships between landscape characteristics and mean residence time need fuller appraisal though nestedcatchments investigations.

From a UK perspective, there is a general lack of experience in the use of stable isotopes for investigating catchment hydrology (Darling et al., 2003). This stems from the often complex climatic and catchment-specific factors controlling their composition, such that for many routine monitoring purposes their measurement is deemed to be of little practical use so data sets are scarce. From a catchment hydrology perspective however, it is this complexity that provides the potential for insights that are less readily available from other methods. Stable isotope tracers therefore have the potential to play an important role as the hydrological research community faces increasing pressure to provide improved process understanding and quantitative knowledge at the larger scales where water resource decision-making occurs (Healy, 2001; Naiman et al., 2001; Soulsby et al., 2003). These efforts are likely to be most productive in settings where hydrological processes can be examined at nested catchment scales, where pre-existing process understanding gained from small, intensively monitored headwater catchments may help interpret in relation to behaviour at the larger scale (McGuire et al., 2005; Soulsby et al., 2004 ${ }^{1}$ ).

This paper reports the use of $\delta^{18} \mathrm{O}$ measurements as a natural tracer to provide insight into hydrological flow paths and mean residence times for nested sub-catchments in the mesoscale $\left(233 \mathrm{~km}^{2}\right)$ Feugh catchment in the northeast of Scotland. Previous hydrological studies at this site have focused on the use geochemical tracers to understand the role of hydrological flow paths over a range of temporal and spatial scales and examine how water quality may be affected by environmental change (Wade et al., 2001; Soulsby et al., 2003, 2004). The use of $\delta^{18} \mathrm{O}$ measurements was anticipated to build on this by providing complimentary insight on catchment residence times and the mixing of different hydrological sources that would further elucidate the influence of scale on hydrological functioning. This parallels ongoing work to upscale hydrological understanding in the Feshie catchment in the Cairngorm Mountains of Scotland as part of the NERC-funded CHASM (Catchment Hydrology And Sustainable Management) initiative (Rodgers et al., 2004; Soulsby et al., 2004 ${ }^{1}$ ). The aims of the paper therefore are to: (i) characterise the spatial and temporal variation in $\delta^{18} \mathrm{O}$ of precipitation and stream waters in the Feugh catchment; (ii) establish the main hydrological processes influencing stream water $\delta^{18} \mathrm{O}$ using information from other geochemical tracers; (iii) estimate the mean residence time of runoff in the

\footnotetext{
${ }^{1}$ Soulsby, C., Tetzlaff, D., Rodgers, P. Dunn, S., and Waldron, S.: Dominant runoff processes, streamwater mean residence times and controlling landscape characteristics in a mesoscale catchment, J. Hydrol., in review, 2004.
}

catchment and its major sub-catchments; and (iv) assess the extent to which these are influenced by catchment scale, topography and soil characteristics.

\section{Study area}

The Water of Feugh drains $233 \mathrm{~km}^{2}$ in northeast Scotland (Fig. 1a). The catchment is predominantly upland in character, with an altitude range from $70-776 \mathrm{~m}$. The climate is cool and wet, with an estimated mean annual precipitation of $1130 \mathrm{~mm}$ which mainly falls as rain, though snow does occur during the winter months and snow pack accumulation can occur in cold years (Soulsby et al., 1997). The catchment is mainly (ca. 85\%) underlain by granite, though the most northern parts of the catchment, as well as the southern boundary in the Water of Dye sub-basin, are underlain by metamorphic rocks (mainly pelites and psammites) (Fig. 1b).

The Feugh is formed by three tributaries (the Dye, Aven and Upper Feugh), which are confluent some $4 \mathrm{~km}$ upstream of Heugh Head (the gauging station at the catchment outfall) (Fig. 1a). The largest of these sub-catchments (at $90 \mathrm{~km}^{2}$ ), the Water of Dye, is the most southerly and drains a granitedominated area, although there is a significant outcrop of schist in its headwaters (Fig. 1b). The sub-catchment is characterised by extensive plateaux areas on the interfluves above $450 \mathrm{~m}$ that are dominated by peats (up to $5 \mathrm{~m}$ deep) and peaty podzols $(<1 \mathrm{~m}$ deep) (Fig. 1c). Only on the more incised catchment slopes do the most freely draining humus iron podzols ( $<1 \mathrm{~m}$ deep) occur and the main river valley bottoms generally have freely draining alluvial deposits and soils.

The Water of Feugh sub-catchment is the most northerly with granite-dominated headwaters grading to metamorphic rocks in the lower catchment near Powlair. In contrast to the Dye, the catchment has been over widened by glacial erosion and meltwater action, with more restricted plateaux areas, lower peat coverage and larger areas of more freely draining podzols on steeper slopes (Fig. 1c). More extensive alluvial deposits of sands and gravels ( $>10 \mathrm{~m}$ deep) occupy the valley floor, especially in the Powlair area. The smallest sub-catchment $\left(30 \mathrm{~km}^{2}\right)$ is occupied by the Water of Aven, which lies between the Dye and Upper Feugh. The upper sub-catchment drains an extensive peat-covered plateau underlain by granite, but downstream the valley is very steeply incised, mainly due to erosion by meltwaters. In the lowest part of the sub-catchment, extensive alluvial deposits form a fan, where the Aven confluences with the upper Feugh, and further extensive deposits fill the valley floor between this confluence and the gauging station of Heugh Head (Fig. 1b).

Given the topography and soil coverage in the catchment, land use is largely restricted to grouse (Lagopus lagopus) and Red deer (Cervus elaphus) shooting on heather moorland in the upper reaches of all three sub-basins (Fig. 1d). The moorlands are managed by regular burning to retain the mosaic of habitats required by grouse. The long history of 

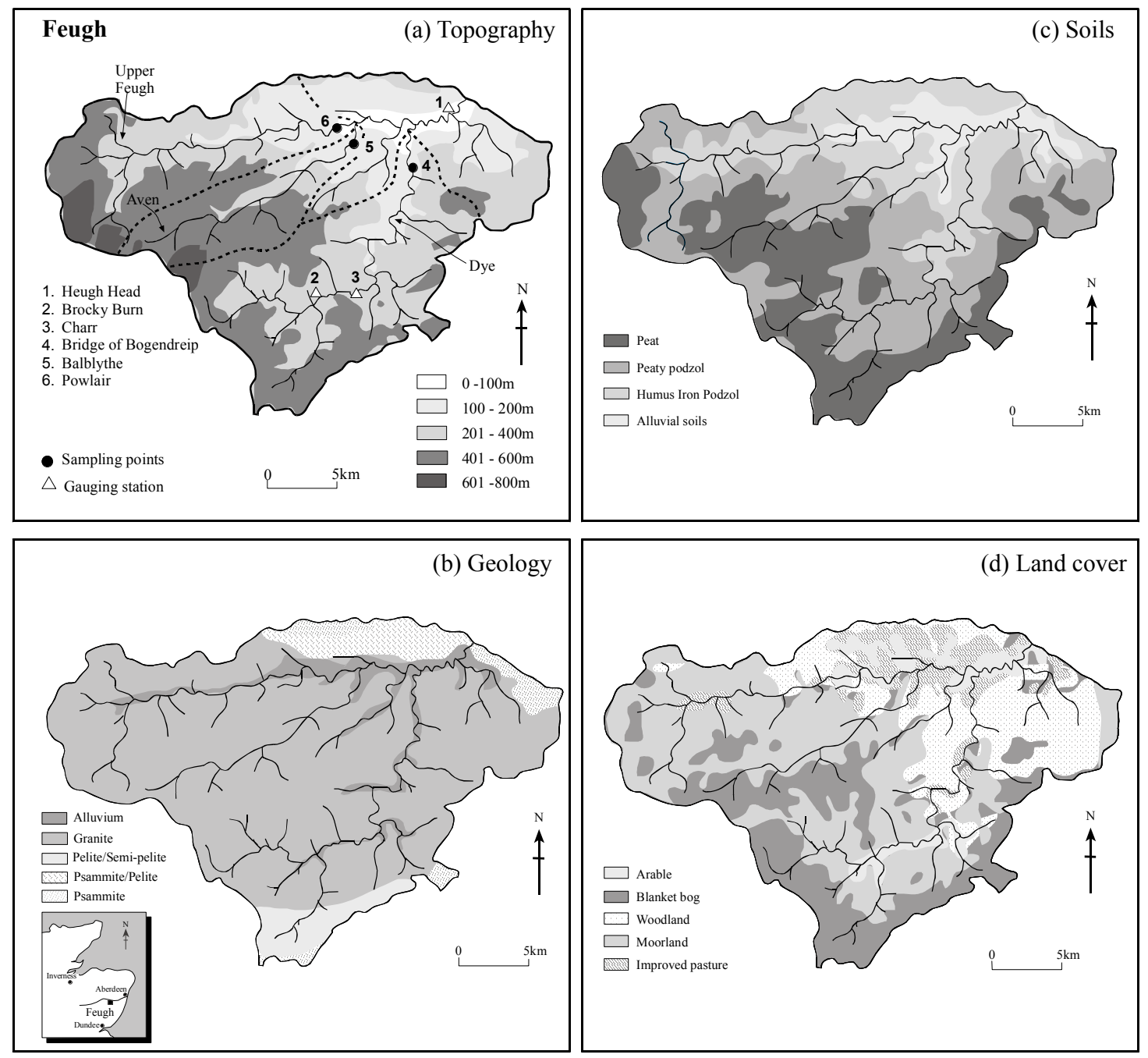

Fig. 1. Catchment maps of the Feugh, showing (a) topography and monitoring network, (b) geology, (c) soil coverage and (d) land cover.

burning may have contributed to peat erosion, as the peat is degraded and extensively "hagged" in many places, particularly in the Aven and upper Feugh catchments (Thompson et al., 2001). This dictates that a high density of ephemeral drainage channels covers the peat, connecting it to the perennial stream channel network. In some places erosion extends to the organo-mineral interface, allowing seepage into the underlying parent material and bedrock. In all three sub-basins, agriculture occupies the better floodplain soils, though this mainly comprises livestock grazing (Fig. 1d). The more extensive coverage of freely draining soils in the upper Feugh sub-basin and the lower catchment above and below the tributary confluences is the main area where arable farming occurs (Table 1). Some of the valley hillslopes are forestcovered, most notably in the lower valleys of the Water of Dye and Upper Feugh. In the former case, the forestry is mainly commercial woodlands, whilst in the latter, semi- natural forests of Scots Pine (Pinus sylvestris) predominate (Fig. 1d, Table 1).

The mean annual runoff at Heugh Head, the catchment outfall, is $5.55 \mathrm{~m}^{3} \mathrm{~s}^{-1}$, with a range between a $\mathrm{Q}_{95}$ of $0.9 \mathrm{~m}^{3} \mathrm{~s}^{-1}$ and a $\mathrm{Q}_{10}$ of $11.4 \mathrm{~m}^{3} \mathrm{~s}^{-1}$. Water balance estimates suggest annual evaporation rates of ca. $300 \mathrm{~mm}$. In addition to this site, the Scottish Environment Protection Agency (SEPA) also monitor flows for the $42 \mathrm{~km}^{2}$ Charr catchment in the Water of Dye (Fig. 1a). Further flow records in the Water of Dye were also collected from Brocky Burn, where a flume and pressure transducer were established by the University of Aberdeen (Dawson, 1999). This gave accurate nested flow records for 233, 42 and $1.3 \mathrm{~km}^{2}$ for the Feugh, Charr and Brocky Burn respectively (Soulsby et al., 2003). 
Table 1. Characteristics of the Feugh catchment.

\begin{tabular}{|c|c|c|c|c|c|c|c|c|c|c|c|c|c|}
\hline & & & \multicolumn{4}{|c|}{ Geology } & \multicolumn{4}{|c|}{ Soils } & \multicolumn{3}{|c|}{ Land Use } \\
\hline & 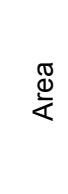 & $\begin{array}{l}\frac{0}{0} \\
\frac{1}{2} \\
\frac{+}{\pi} \\
\frac{1}{\pi} \\
\mathbb{0} \\
\sum\end{array}$ & 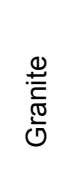 & 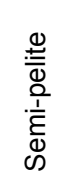 & 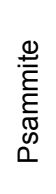 & $\begin{array}{l}\frac{\bar{\sigma}}{3} \\
\frac{\overline{\bar{k}}}{\bar{k}}\end{array}$ & $\begin{array}{l}\overrightarrow{\mathbb{N}} \\
\mathbb{D} \\
0\end{array}$ & $\begin{array}{l}\bar{O} \\
N \\
0 \\
0 \\
0 \\
\geq \bar{D} \\
0 \\
0 \\
0\end{array}$ & 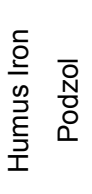 & 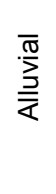 & $\begin{array}{l}\frac{0}{0} \\
\frac{\pi}{0} \\
\frac{0}{0} \\
3\end{array}$ & 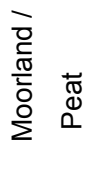 & 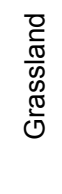 \\
\hline & $\mathrm{km}^{2}$ & $\mathrm{~m}$ & $\%$ & $\%$ & $\%$ & $\%$ & $\%$ & $\%$ & $\%$ & $\%$ & $\%$ & $\%$ & $\%$ \\
\hline 1. Brocky Burn & 1.3 & 419 & 100 & 0 & 0 & 0 & 84.1 & 15.9 & 0 & 0 & 0 & 100 & 0 \\
\hline 2. Charr & 41.8 & 420 & 73.3 & 21.5 & 3.2 & 1 & 65.9 & 34.1 & 0 & 0 & 0 & 99.4 & 0.6 \\
\hline 3. Bogendreip & 90.1 & 357 & 80.2 & 12.3 & 2.8 & 4.2 & 48.5 & 38.0 & 13.2 & 0 & 22.1 & 72.4 & 4.2 \\
\hline 4. Aven & 30.1 & 427 & 99.2 & 0 & 0 & 0.8 & 55.7 & 30.3 & 13.2 & 0.8 & 5.6 & 92.7 & 1.6 \\
\hline 5. Powlair & 61.1 & 356 & 86.5 & 0 & 5.0 & 8.4 & 19.4 & 38.8 & 36.9 & 4.9 & 10.1 & 74.2 & 9.5 \\
\hline 6. Heugh Head & 233 & 329 & 78.5 & 4.8 & 8.5 & 7.9 & 32.1 & 34 & 26 & 7.9 & 18.1 & 68.2 & 10.7 \\
\hline
\end{tabular}

\section{Methods}

Samples of stream water for the 2001-2002 hydrological year were collected at approximately weekly intervals at six sites in the catchment (Fig. 1a). The availability of flow data for the three nested catchments at Brocky Burn $\left(1.3 \mathrm{~km}^{2}\right)$, Charr $\left(42 \mathrm{~km}^{2}\right)$ and Heugh Head $\left(233 \mathrm{~km}^{2}\right)$, provided a concentration of sampling sites down the Water of Dye sub-basin, which was further supplemented by Bogendreip $\left(90 \mathrm{~km}^{2}\right)$ (Fig. 1a). Two additional sampling sites were located on the other two sub-basins of the Feugh, the Aven and the Upper Feugh, in order to characterise their overall contribution to the isotopic signature of stream water leaving the catchment at Heugh Head (Fig. 1a). Catchment precipitation was sampled at approximately the same weekly intervals as stream water from a rain collector located in the Water of Dye catchment at Charr. This was located at an altitude of $300 \mathrm{~m}$ which was assumed to be representative of catchment-average inputs. Although the potential influence of altitude on precipitation $\delta^{18} \mathrm{O}$ was recognised (McGuire et al., 2005), resource constraints mitigated against a second set of precipitation samples.

All samples were collected and stored according to standard procedures (cf. Clark and Fritz, 1997) and analysed at the Scottish Universities Environment Research Centre (SUERC) using a gas source isotope ratio mass spectrometer. Ratios of ${ }^{18} \mathrm{O} /{ }^{16} \mathrm{O}$ are expressed in delta units, $\delta^{18} \mathrm{O}$ (\%o, parts per mille) defined in relation to V-SMOW (Vienna standard mean ocean water). The analytical precision was $\pm 0.1 \%$ o. Stream water samples were also analysed for Gran alkalinity by acidimetric titration to end points of $\mathrm{pH} 4.5$,
4.0 and 3.0. This approximates the chemically conservative parameter of Acid Neutralizing Capacity (ANC) in natural waters where aluminium concentrations are low (Neal et al., 2001) thus allowing it to be used for hydrograph separation at each site using a classical two component mixing model to quantify groundwater contributions to annual runoff. This is described in detail by Soulsby et al. (2003).

A range of models are available for assessing catchment residence times using tracer data (Maloszewski and Zuber, 1982; Turner and Barnes, 1998). Given the basic data set available, the sine wave method was used for the Feugh data, which compares the amplitude of seasonal variations in $\delta^{18} \mathrm{O}$ in precipitation and stream flow, and uses the degree of damping to estimate residence time (Unnikrishna et al., 1995). This assumes an exponential distribution of residence times and is particularly useful in catchments where short residence time flow paths (such as overland flow from the dominant peaty soils in the Feugh) are important as it is biased to a young water component (Maloszewski et al., 1983; Stewart and McDonnell, 1991; Unnikrishna et al., 1995; Rodgers et al., 2005). In contrast, other commonly used models, such as the exponential piston-flow model, are better suited to catchments dominated by delayed sub-surface flows. The short (1 year) run of data precluded the application of the more accurate convolutional integral approach where antecedent precipitation inputs would need to be accurately modelled (Vitvar and Balderer, 1997). In the context of the simpler sine wave method, the short run of data was less problematic. Earlier work in the from other montane catchments in northern Scotland showed that the range and seasonal pattern of $\delta^{18} \mathrm{O}$ values in observed precipitation 
during the study year were broadly representative of a 3 year period of weekly samples collected between 1995 and 1998 (cf. Soulsby et al., 2000).

Seasonal trends in $\delta^{18} \mathrm{O}$ in precipitation and stream water were modelled using periodic regression analysis (Bliss, $1970)$ to fit seasonal sine wave curves to annual $\delta^{18} \mathrm{O}$ variations in precipitation and stream water (cf. DeWalle et al., 1997), defined as:

$\delta^{18} \mathrm{O}=X+A[\cos (c t-\theta)]$

where $\delta^{18} \mathrm{O}$ is the modelled $\delta^{18} \mathrm{O}(\%), X$ is the weighted mean annual measured $\delta^{18} \mathrm{O}(\%), A$ is the measured $\delta^{18} \mathrm{O}$ annual amplitude (\%o), $c$ is the radial frequency of annual fluctuations $\left(0.017214 \mathrm{rad} \mathrm{d}^{-1}\right), t$ is the time in days after the start of the sampling period $(01 / 10 / 01)$, and $\theta$ is the phase lag or time of the annual peak $\delta^{18} \mathrm{O}$ in radians. Sine wave models fitted to precipitation and stream water $\delta^{18} \mathrm{O}$ variations were used and the mean residence time $(T)$ of water leaving the system was calculated as:

$T=c^{-1}\left[(A z 2 / A z 1)^{-2}-1\right]^{0.5}$

where $A z 1$ is the amplitude of precipitation $\delta^{18} \mathrm{O}(\%), A z 2$ is the amplitude of the stream water $\delta^{18} \mathrm{O}(\%)$ and $c$ is the radial frequency of annual fluctuations as defined in model (1).

Application of residence time models to stream water data in larger catchments over longer timescales is problematic. The models generally assume some steady state condition in catchment function, which is obviously unrealistic. In some studies this results in high flow samples being omitted from the analysis and baseflow residence times being estimated (e.g. McGuire et al., 2005). In this context, the precipitation $\delta^{18} \mathrm{O}$ inputs are accordingly weighted to try and reflect the signature of recharge, particularly in catchments with marked climatic seasonality (e.g. Uhlenbrook et al., 2002). However, in a flashy catchment such as the Feugh, where precipitation is evenly distributed in most years, meaningfully defining "baseflow" is extremely difficult. Moreover, in the wet, cool montane climate, high soil moisture deficits are not common. Given this context, sine curves were fitted to weighted monthly mean precipitation data and stream water data to give a snap-shot first approximation of mean residence times during this particular year. Given the operation of responsive hydrological pathways throughout the year (i.e. effectively no baseflow period) precipitation samples were not weighted to estimates the $\delta^{18} \mathrm{O}$ signature of recharge. Subsequent volume-weighted means of $\delta^{18} \mathrm{O}$ in precipitation and stream water showed approximate mass balance (see Sect. 4.1). Given the simple nature of this model, the size and complexity of the Feugh catchment, together with the resolution of precipitation inputs and stream water outputs, the results represent preliminary estimates of mean residence times. The main aim of the residence time modelling was

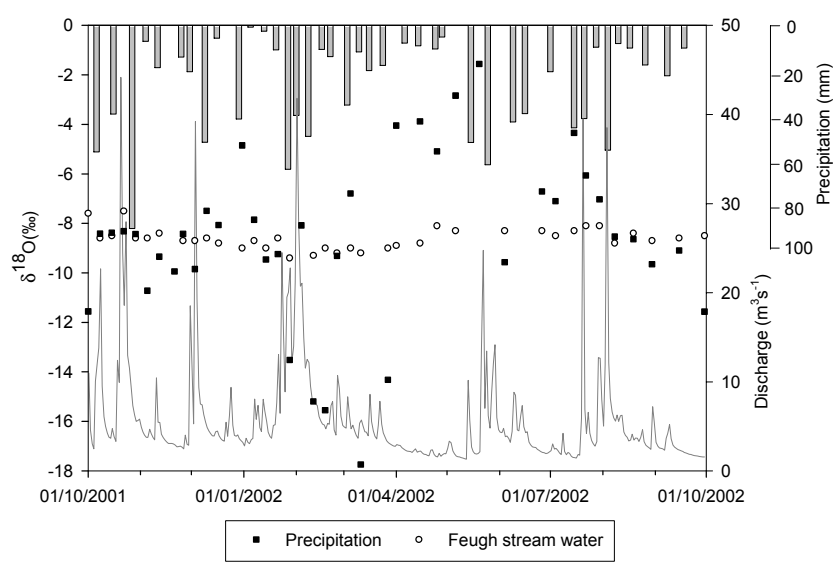

Fig. 2. Temporal variation in precipitation and stream water $\delta^{18} \mathrm{O}$, annual run-off and rainfall for the Feugh catchment (01/10/200130/09/2002).

to compare different nested catchment responses to examine how variable isotopic responses to precipitation may provide insight into the internal hydrological functioning of the Feugh catchment. Therefore, the exponential sine wave approach allows comparison of the natural variation between different sub-catchment stream water $\delta^{18} \mathrm{O}$ signatures. As such, the results can only be taken as indicative estimates of mean residence times and can only be compared to results from other sites with caution. Nonetheless, studies elsewhere have suggested that the model is likely to be useful for such a first approximation (Stewart and McDonnell, 1991; Soulsby et al., 2001; Asano et al., 2002). Furthermore, the short run of data and the relatively coarse temporal and spatial sampling procedure precluded reasonable application of more complex residence time estimation methods (e.g. Maloszewski and Zuber, 1982; McGuire et al., 2002; Kirchner et al., 2000) which are often possible with data collected at a finer temporal distribution.

\section{Results and discussion}

4.1 Seasonal variation in precipitation and stream water $\delta^{18} \mathrm{O}$

Catchment precipitation showed marked seasonal variation, with winter precipitation (November to April: mean $-9.73 \%$ ) more ${ }^{18} \mathrm{O}$-depleted than summer rainfall (May to October: mean 7.42\%o) (Table 2). This follows the anticipated seasonal pattern of precipitation $\delta^{18} \mathrm{O}$ whereby winter months are dominated by colder northerly and easterly air masses that bring rain and snow which, due to low temperatures, is more ${ }^{18} \mathrm{O}$-depleted (Fig. 2). By contrast, summer weather systems are mainly south-westerly in origin, resulting in more ${ }^{18} \mathrm{O}$-enriched precipitation. Despite precipitation in the Feugh generally following this seasonal pattern, it can 
Table 2. Arithmetic mean, range and standard deviation of $\delta^{18} \mathrm{O}(\% \circ)$ in the Feugh catchment $(01 / 10 / 2001-30 / 09 / 2002)$.

\begin{tabular}{lcccc}
\hline & Mean & Minimum & Maximum & Standard deviation \\
\hline Winter/Spring precipitation & -9.58 & -17.7 & -3.9 & 3.59 \\
Summer/Autumn precipitation & -7.42 & -11.6 & -1.6 & 2.79 \\
& & & & \\
1. Brocky Burn & -8.52 & -10.2 & -7.0 & 0.72 \\
2. Charr & -8.61 & -9.5 & -7.2 & 0.46 \\
3. Bogendreip & -8.82 & -9.7 & -7.8 & 0.43 \\
4. Aven & -9.06 & -9.8 & -8.0 & 0.31 \\
5. Powlair & -9.15 & -10.0 & -8.3 & 0.29 \\
6. Heugh Head & -8.61 & -9.4 & -7.5 & 0.42 \\
\hline
\end{tabular}

be seen that there is a considerable amount of scatter; though in general extreme $\delta^{18} \mathrm{O}$ values were in relative small rainfall volumes. The most ${ }^{18} \mathrm{O}$-depleted precipitation occurred in small snow-influenced events at the end of the winter months in February and March (Fig. 2). This was when the influence of colder weather systems was most sustained compared with the general influence of milder, maritime weather systems earlier in the winter. Markedly ${ }^{18} \mathrm{O}$-depleted depleted precipitation was observed in spring albeit in small events, when more ${ }^{18} \mathrm{O}$-enriched precipitation would be anticipated. However, the hydrological year of 2001-2002 was substantially cooler and wetter than normal and air masses with an arctic origin can affect the Scottish climate well into the spring. Thus, this transition appears to occur very abruptly (Fig. 2), although the relative lack of rainfall/storm activity during April means that this shift is over-emphasized in relation to effective precipitation.

In comparison to precipitation, stream water $\delta^{18} \mathrm{O}$ is highly damped at all sites, reflecting the influence of longer residence time runoff sources with more stable $\delta^{18} \mathrm{O}$, which effectively integrates seasonally variable precipitation inputs (see Heugh Head response in Fig. 2). However, stream water $\delta^{18} \mathrm{O}$ response for different sites exhibits notable differences, which in turn reflect important sub-catchment variation in hydrological function (Table 2). The most variable site in the catchment is the $1.3 \mathrm{~km}^{2}$, peat-dominated Brocky Burn sub-catchment $\left(\delta^{18} \mathrm{O}\right.$ range 3.2\%o: Table 2). Increasing scale downstream in the Water of Dye leads to a reduction in $\delta^{18} \mathrm{O}$ range observed for the $42 \mathrm{~km}^{2}$ Charr subcatchment (range 2.3\%o), with the downstream site at Bogendreip $\left(90 \mathrm{~km}^{2}\right)$ displaying a further reduction in range $(1.9 \%)$. The overall $\delta^{18} \mathrm{O}$ range measured at the catchment outfall at Heugh Head $\left(233 \mathrm{~km}^{2}\right)$ shows no difference to that measured at Bogendreip (1.9\%o), despite the influence of stream water contributions from the other two sub-basins, the Water of Aven $\left(30 \mathrm{~km}^{2}\right)$ and the Water of Feugh at Powlair $\left(61 \mathrm{~km}^{2}\right)$. These two catchments exhibit the lowest overall range and variability in $\delta^{18} \mathrm{O}$ over the year (ranges of 1.8 and 1.7\%orespectively: Table 2 ).
In addition to the annual range for each site, there are also variations of $0.63 \%$ in the mean $\delta^{18} \mathrm{O}$. Brocky Burn has the most ${ }^{18} \mathrm{O}$-enriched mean stream water overall $(-8.52 \%$ o). The second highest $\delta^{18} \mathrm{O}$ was observed at both Charr and Heugh Head, which show the same annual mean $(-8.61 \%$ : Table 2). Bogendreip is intermediate $(-8.82 \%$ ), whilst the Water of Aven and Powlair show the lowest, most ${ }^{18} \mathrm{O}$ depleted means ( -9.06 and $-9.15 \%$ : Table 2$)$. The volume weighted mean precipitation was $-8.40 \%$, which is reasonably close to that of Heugh Head and the Water of Dye sites, indicating an approximate mass balance over the year.

\subsection{Stream water $\delta^{18} \mathrm{O}$ response to flow}

Figure 3 shows the stream water $\delta^{18} \mathrm{O}$ time series for the six sub-catchments during the 2001-2002 hydrological year. As with precipitation, stream waters exhibit seasonal differences, being generally ${ }^{18} \mathrm{O}$-depleted during the winter months when rainfall and snowmelt generate the highest flows. The effect of more ${ }^{18} \mathrm{O}$-enriched precipitation is evident in summer stream water $\delta^{18} \mathrm{O}$. However, it is also notable that the most ${ }^{18} \mathrm{O}$-enriched samples occur during the first month of the sampling period in association with the two largest flows sampled for the year (Fig. 2). Thus, in addition to the seasonal precipitation influence determining stream water $\delta^{18} \mathrm{O}$ on a catchment-wide basis, specific hydrological events (and therefore variability in sub-catchment hydrological behaviour) can also lead to differences in isotopic composition between sites. This can be most readily shown by comparing $\delta^{18} \mathrm{O}$ with corresponding stream water alkalinity time series (Fig. 3).

Gran alkalinity has proven utility as a tracer in the UK uplands. It effectively distinguishes between low alkalinity high flows derived mainly from acidic, organic soil horizons which generate rapid overland flow or shallow sub-surface storm flow; and higher alkalinity water from lower soil horizons and/or groundwater which dominates base flows (Hill and Neal, 1997; Wade et al., 1999). As a result, Gran alkalinity can be seen to vary predictably with flow in the Feugh and 

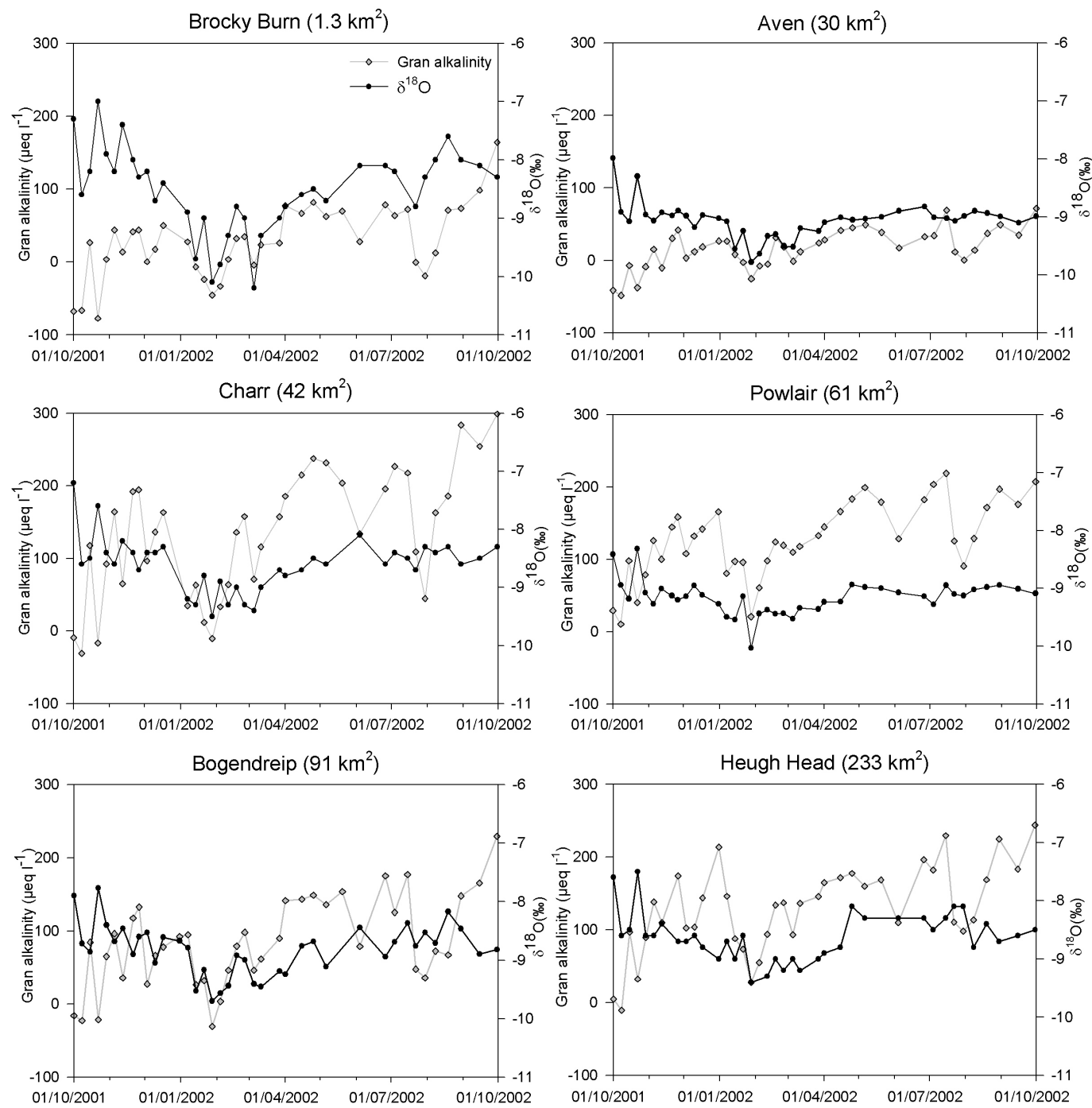

Fig. 3. Temporal co-variation in stream water $\delta^{18} \mathrm{O}$ and alkalinity for Feugh sub-catchments.

its sub-catchments (Fig. 4, but see Soulsby et al., 2003 for a full analysis). Stream water samples from the different sites show alkalinity convergence at high flows, but base flows relate closely to geology. Hence the low alkalinity baseflows in the granite-dominated Water of Aven, but much high baseflow alkalinity at Charr flume where metamorphic rocks underlie the upper catchment. The availability of stream water alkalinity measurements sampled at the same time as $\delta^{18} \mathrm{O}$ for each of the six sites therefore acts as a surrogate for flow (especially for ungauged sites), and provides insight into the role of different hydrological flow paths that will be affecting the observed $\delta^{18} \mathrm{O}$.

It is apparent that there is considerable event-related variation in $\delta^{18} \mathrm{O}$ from sample to sample for the majority of sites (Fig. 3). At the most variable site, Brocky Burn, the two most enriched $\delta^{18} \mathrm{O}$ samples during the first month of sampling are particularly marked. These relate to two of the largest sampled flows of the year (as indicated by the low stream water alkalinity), with $\delta^{18} \mathrm{O}$ enrichment in the intervening samples (Fig. 3). The same effect is observed at the other Feugh monitoring sites. Rather than these peaks relating closely to maximum precipitation $\delta^{18} \mathrm{O}$ (Fig. 2), the occurrence of stream water $\delta^{18} \mathrm{O}$ maxima at this time present some uncertainty over the role of antecedent precipitation in setting stream water $\delta^{18} \mathrm{O}$ during the initial phase of the study. Furthermore, initial precipitation $\delta^{18} \mathrm{O}$ for October 2001 are not as enriched as stream water during this period (Fig. 2). It seems likely that catchment runoff is dominated by the displacement of ${ }^{18} \mathrm{O}$-enriched summer precipitation stored in the catchment prior to sampling, especially as these October events followed a six-week period with limited high flows. Tracer studies during in the Scotland have previously shown such displacement of "old" pre-event water by "new" precipitation in summer events (Jenkins et al., 1994). 

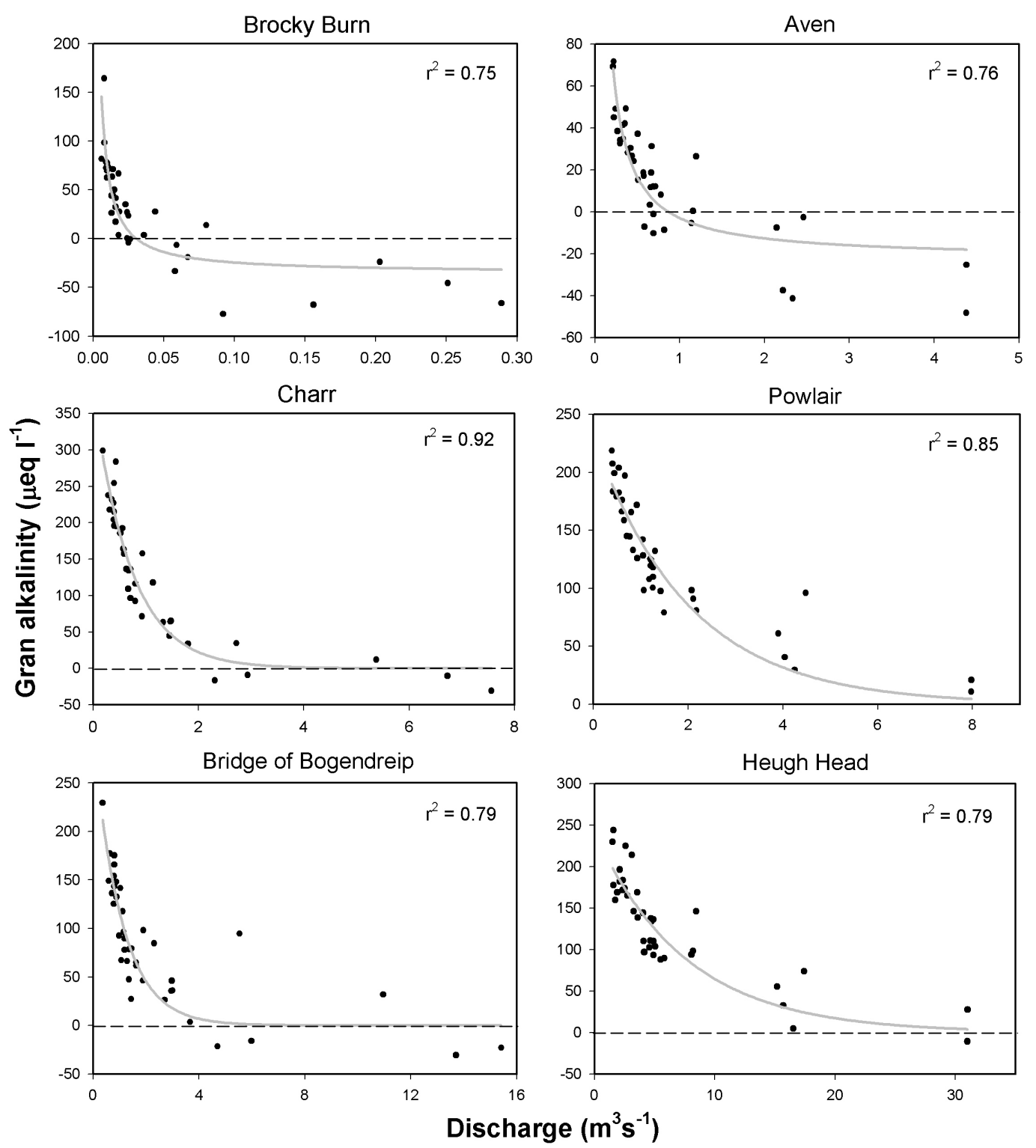

Fig. 4. Alkalinity variation with flow for sub-catchment sampling sites in the Feugh.

After this initial period, stream water $\delta^{18} \mathrm{O}$ generally reflected precipitation more directly. The small, peatdominated Brocky Burn shows the most marked response to more depleted winter precipitation events with 3 particularly ${ }^{18} \mathrm{O}$-depleted samples between January and March 2002 (Fig. 3). The first two of these occurred in January following on from snow falls in the latter half of December. However, the most ${ }^{18} \mathrm{O}$-depleted precipitation samples do not occur until the more prolonged colder weather systems of February and March (Fig. 2). Stream water $\delta^{18} \mathrm{O}$ then exhibits an increase through the remainder of March and then April. Although precipitation was still ${ }^{18} \mathrm{O}$-depleted over this period, it was not reflected in stream water $\delta^{18} \mathrm{O}$ due to the rainfall totals being low and causing only small increases in flow (Fig. 3). However, given the wet, cool conditions, soil moisture deficits did not accumulate and stream water $\delta^{18} \mathrm{O}$ during the summer months at Brocky Burn exhibits a rapid response to more ${ }^{18} \mathrm{O}$-enriched summer precipitation. In particular, there are two periods of high flow in the summer at the start of June and end of July (where alkalinity decreases significantly), which result in sustained increases in stream water $\delta^{18} \mathrm{O}$ (compared with downstream sites) over more stable base flow conditions for the intervening samples (Fig. 3).

The general seasonal pattern of stream water $\delta^{18} \mathrm{O}$ observed at Brocky Burn is replicated at the increasing downstream scales of Charr, Bogendreip and Heugh Head, albeit in a more damped manner (Fig. 3). The stream water $\delta^{18} \mathrm{O}$ time series for the Water of Aven and the Water of Feugh 

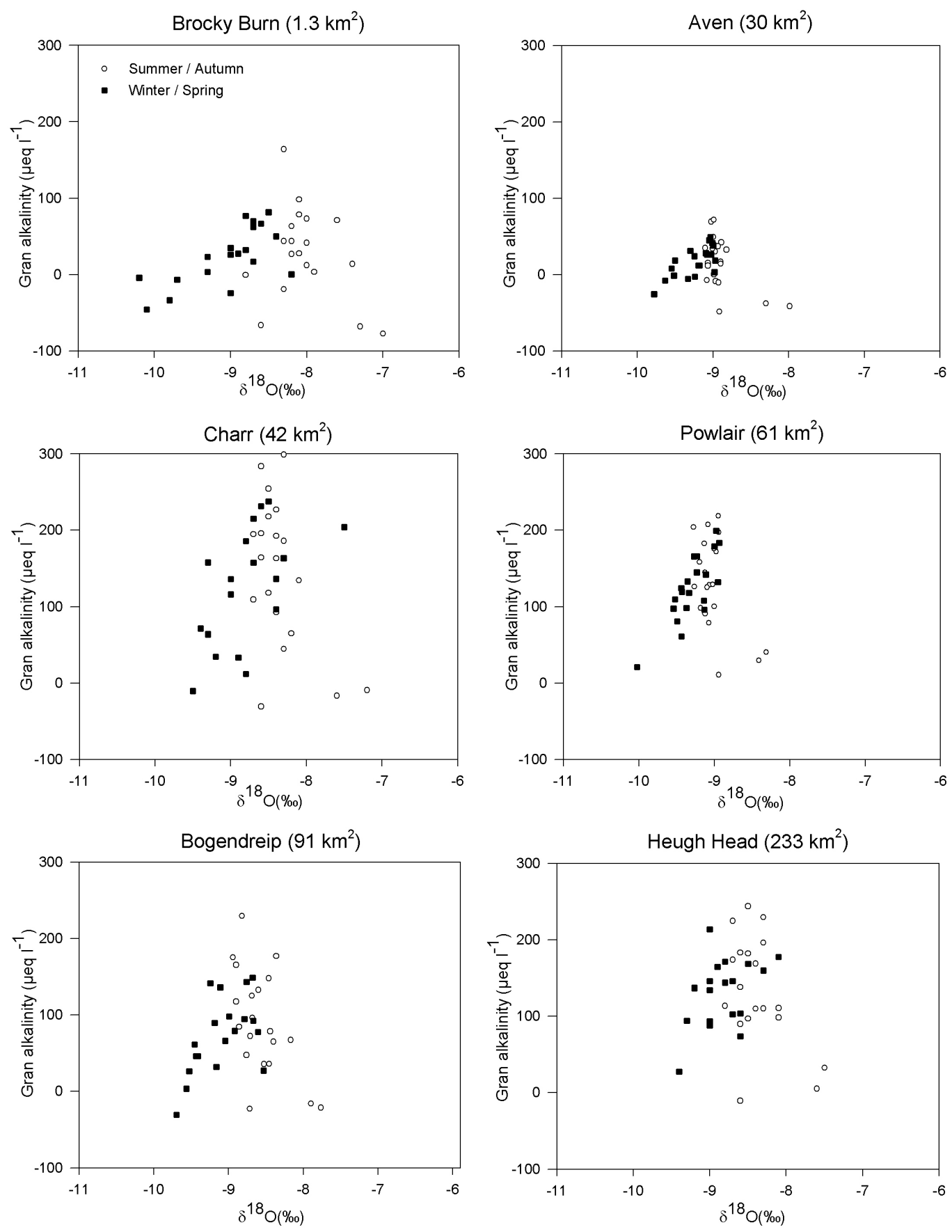

Fig. 5. Mixing plots for stream water $\delta^{18} \mathrm{O}$, showing seasonal and flow (alkalinity) related variation.

at Powlair, however, as well as being slightly more ${ }^{18} \mathrm{O}$ depleted, are also notably less varied in terms of response to short-term hydrological variation. The damped $\delta^{18} \mathrm{O}$ for the Water of Aven initially appears surprising, given its relatively high peat coverage (56\% cf. Charr $66 \%$ : Tables 1 and 2). However, the extensive erosion of the blanket peat in the headwaters of the Aven probably leads to more significant recharge of groundwater and therefore longer flow paths (Boorman et al., 1995; Soulsby et al., 2004). However, it is also probable that this reflects the influence of the more freely draining mineral soils that cover the steeper slopes of the catchment as well as the significant alluvial deposits at the base of the catchment as it emerges from its incised valley. In contrast, Charr has only relatively confined valley bottom alluvial deposits suggesting that there is more mixing and greater storage in the Aven to dampen variation in 
Table 3. Precipitation and flow-weighted mean $\delta^{18} \mathrm{O}$, mean modelled $\delta^{18} \mathrm{O}$ and amplitude, approximate mean residence times and estimated groundwater flow contributions for sub-catchment sites in the Feugh (2001-02). Groundwater proportions based on annual two-component mixing analysis using Gran alkalinity (see Soulsby et al., 2004).

\begin{tabular}{|c|c|c|c|c|c|c|}
\hline$(\%)$ & $\begin{array}{l}\text { Volume/Flow Weighted Mean } \\
\qquad(\%)\end{array}$ & $\begin{array}{c}\text { Modelled Mean } \\
(\%)\end{array}$ & $\begin{array}{c}\text { Amplitude } \\
\text { (months) }\end{array}$ & $\begin{array}{l}\text { Mean residence time } \\
\text { (months) }\end{array}$ & $\begin{array}{c} \pm 95 \% \text { Confidence Interval } \\
\text { to annual flow }\end{array}$ & $\%$ Groundwater contribution \\
\hline Precipitation & -8.39 & -8.39 & 1.36 & & & \\
\hline 2. Charr & -8.59 & -8.60 & 0.39 & 6.5 & 4.1 & 38.4 \\
\hline 3. Bogendreip & -8.86 & -8.82 & 0.40 & 6.3 & 4.1 & 36.6 \\
\hline 4. Aven & -9.08 & -9.06 & 0.23 & 11.3 & 6.7 & 42.3 \\
\hline
\end{tabular}

stream water $\delta^{18} \mathrm{O}$. Previous studies using alkalinity-based end member mixing to perform hydrograph separations in the catchment have suggested this to be the case (Soulsby et al., 2003, 2004). A similar influence is observed for the most damped $\delta^{18} \mathrm{O}$ time series for the Water of Feugh at Powlair (Fig. 3), given that this is the sub-catchment where the influence of freely draining humus iron podzols and valley bottom alluvial aquifer deposits is most significant (Fig. 1, Table 1). It is important to note that the term mixing is used in this context to conceptually describe the various processes of $\delta^{18} \mathrm{O}$ damping rather than implying the physical mixing across flow lines in sub-surface flows.

These $\delta^{18} \mathrm{O}$ and alkalinity variations in stream water can be viewed conceptually as the combination of two components: a relatively stable base flow end member and a seasonally variable storm flow end member. This conceptualisation is consistent with the two-component end member mixing previously used to assess the hydrology of the Feugh based on alkalinity data alone (Soulsby et al., 2003, 2004). Figure 5 shows this relationship more clearly, presenting seasonally differentiated $\delta^{18} \mathrm{O}$-alkalinity mixing plots. As in Fig. 3, alkalinity measurements are used to provide a more direct indication of hydrological sources affecting measured stream water $\delta^{18} \mathrm{O}$. Theoretically the influence of seasonally variable precipitation, but relatively evenly distributed rainfall amounts mean this should result in an approximately triangular shaped plot of $\delta^{18} \mathrm{O}$ and alkalinity. This will reflect a low alkalinity, seasonally variable storm flow end member (with low $\delta^{18} \mathrm{O}$ during winter and higher $\delta^{18} \mathrm{O}$ during summer), which mixes with higher alkalinity base flow waters with more stable, intermediate $\delta^{18} \mathrm{O}$. At most sites this conceptual structure is apparent, although there are significant inter-site differences.

As expected, the most responsive site at Brocky Burn shows the clearest seasonally differentiated $\delta^{18} \mathrm{O}$ variation (Fig. 5). Sites where there is less distinction between summer and winter samples implies a greater mixing of source waters and this is most evident for Powlair and the Aven given their more damped $\delta^{18} \mathrm{O}$ variability observed in Fig. 3. The expected downstream increase in the mixing of sources with scale is apparent from Brocky Burn to Charr to Bogendreip and Heugh Head (Fig. 5). Despite this, Heugh Head displays considerable scatter due to the contrasting isotopic signature of sub-catchment drainage that it integrates. These mixing plots also illustrate the degree to which subcatchment base flows (highest alkalinities) are constrained in terms of $\delta^{18} \mathrm{O}$ variation. The least variable Powlair and Aven sites unsurprisingly display the most constant $\delta^{18} \mathrm{O}$ at lower flows, whereas the lowest flow (highest alkalinity) samples for Brocky Burn exhibit notable differences. This can probably be attributed to limited groundwater storage in such a small headwater catchment, which contributes small amount of groundwater that is more seasonally variable, and readily influenced by soil water drainage than larger subcatchments where groundwater storage is more extensive and well mixed. Base flow $\delta^{18} \mathrm{O}$ at Charr appears to be reasonably well defined but variation increases downstream at Bogendreip, and then further at Heugh Head, reflecting the greater mix of isotopic signatures that it receives from the three sub-basins.

\subsection{Estimating sub-catchment mean residence time}

The seasonal $\delta^{18} \mathrm{O}$ trends observed in precipitation and stream water were used to estimate mean residence times using periodic regression analysis to fit seasonal sine wave models to annual $\delta^{18} \mathrm{O}$ time series (Fig. 6). Given the significant variation observed in the weekly precipitation samples, it was necessary to use monthly volume weighted means in order to represent the overall seasonal pattern more reliably. Although the resulting modelled sine wave appears to considerably under-represent the range of precipitation values, reference to Fig. 2 shows that most extreme precipitation $\delta^{18} \mathrm{O}$ values were in small events. This use of weighted monthly means has been used in other studies where high resolution sampling particularly following minor precipitation events with extreme isotope signatures (i.e. those in April 

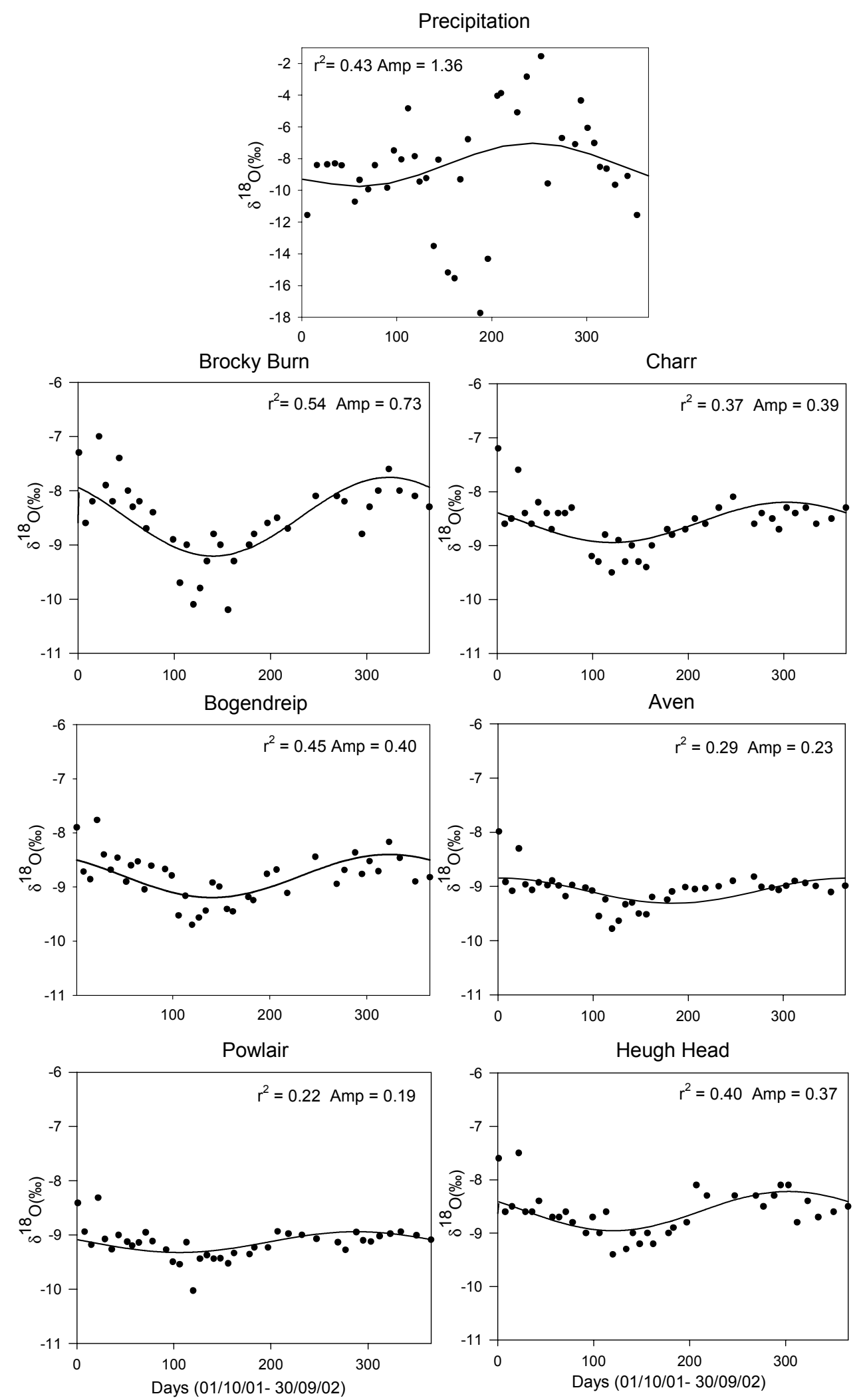

Fig. 6. Fitted annual regression models to $\delta^{18} \mathrm{O}$ for precipitation and stream water in the Feugh. 
Table 4. Pearson coefficients of correlation $r$ between controlling catchment variables and both mean water residence times and groundwater contribution.

\begin{tabular}{lcc}
\hline & $\begin{array}{c}\text { Mean residence } \\
\text { time } r\end{array}$ & $\begin{array}{c}\text { Groundwater } \\
\text { contribution } r\end{array}$ \\
\hline Area & - & 0.66 \\
Mean elevation & -0.14 & -0.65 \\
Min elevation & -0.56 & -0.71 \\
Max elevation & 0.50 & 0.62 \\
Mean slope & 0.82 & 0.74 \\
Max slope & 0.67 & 0.81 \\
Drainage density & 0.59 & 0.84 \\
Soils & & \\
Peat (Responsive soils) & -0.72 & -0.93 \\
Iron Podzol/ Peaty Podzol & 0.60 & 0.70 \\
Alluvial / Humus Iron Podzol & 0.68 & 0.91 \\
Freely draining soils* & 0.72 & 0.93 \\
Land-use & & \\
Heather/Peatland & -0.33 & -0.71 \\
Coniferous woodland & 0.11 & 0.45 \\
Grassland & 0.45 & 0.89 \\
Geology & & \\
Granite & 0.07 & -0.37 \\
Alluvial & 0.46 & 0.86 \\
\hline Groundwater contribution/ & & 0.71 \\
Mean residence times & & \\
\hline
\end{tabular}

* Iron Podzol/Peaty Podzol and Alluvial/Humus Iron Podzol

2002), caused scatter around the seasonal trends in isotopic composition which are more important when investigating behaviour at the annual time scale (e.g. Darling and Talbot, 2003). Flow weighted monthly stream water mean $\delta^{18} \mathrm{O}$ were also calculated for each site (Table 3 ), though these were similar to the arithmetic mean values given in Table 2 and did not affect the modelled amplitude. For example at Heugh Head the modelled amplitude only varied by $0.02 \%$. The modelled curves, particularly for precipitation, simplifies the patterns of variation evident in the data and this is reflected in the strength of correlations between observed and modelled $\delta^{18} \mathrm{O}$ for most sites (i.e. $r^{2}=<0.50$ ). However, the results showed approximately mass balance in terms of weighted means and the fits were statistically robust $(p<0.02$ and generally $<0.01$ ), and the level of fit was generally comparable with results from similar studies (e.g. DeWalle et al., 1997; McGuire et al., 2002; McGuire et al., 2005; Soulsby et al., 2000, 2005).

In terms of stream water sampling sites, those with the least variable $\delta^{18} \mathrm{O}$ stream water (the Aven and Powlair) are those that are least well described by the seasonal sine wave model $\left(r^{2}=<0.3\right.$; Fig. 6). In contrast, modelled $\delta^{18} \mathrm{O}$ for the remaining four sites at Brocky Burn, Charr, Bogendreip and Heugh Head show generally improved fits and larger $\delta^{18} \mathrm{O}$ amplitude values. In line with the general annual variability observed from Table 2 , the significant downstream increase in modelled $\delta^{18} \mathrm{O}$ annual amplitude from the headwater scale of Brocky Burn $\left(1.3 \mathrm{~km}^{2}\right)$ to the sub-catchment scale of Charr $\left(42 \mathrm{~km}^{2}\right)$ has the most significant impact on modelled amplitudes $(0.73 \%$ oto $0.39 \%$ o). However, at the base of the catchment at Heugh Head, despite the much larger catchment only a minimal further decrease in the amplitude of modelled stream water $\delta^{18} \mathrm{O}$ is produced $(0.37 \%$; Fig. 6$)$.

The model described by Eq. (2) was used to translate the results into estimates of mean stream water residence time (Table 3). These also provide an indication of the degree of mixing within each sub-catchment and thus offer a valuable integrated assessment of the differences in the hydrological functioning of the Feugh catchment. In the Water of Dye subcatchment, Brocky Burn has the shortest estimated residence time (3 months) therefore highlights this overall effect. This damping at Charr results in mean residence times increasing (6.5 months), as the catchment size more than doubles at Bogendreip similarity in annual $\delta^{18} \mathrm{O}$ variability results in the similar residence times (6.3 months). Substantially longer residence times were estimated for the Water of Aven and Water of Feugh at Powlair (11.3 and 13.7 months). Despite this, the mean residence time estimated for the catchment outfall at Heugh Head (6.8 months) is virtually the same as Charr and Bogendreip.

\subsection{Influence of catchment characteristics}

The relationships between estimated mean residence times and catchment landscape characteristic were examined in a more formal manner by correlation analysis (Table 4 and Fig. 7). Sub-catchment soil cover had a dominant effect, with percentage cover of responsive peat soils exhibiting a strong negative correlation with mean residence time. Similarly, the percentage coverage of more free draining podzolic and alluvial soils was positively correlated with mean residence time, particularly when combined together as "free drained" soils (Table 1). Mean residence time was also strongly correlated (positively) with mean catchment slope. This obviously influences soil distribution with more freely draining podzols being found on steeper slopes. Nevertheless, the relationship is somewhat counter-intuitive as steeper slopes lead to higher gravitational potential which often results in a negative correlation with mean residence times (McGuire et al., 2005). However in the Feugh and other peat covered catchments in the Scottish highlands (see Soulsby et al., 2004 ${ }^{1}$ ), it seems that the most responsive peat soils are on the flatter hilltops and the steeper slopes have soils that facilitate deeper groundwater recharge.

This is reflected in the mean catchment residence times being also strongly correlated with percentage groundwater contributions to annual runoff in each sub-catchment (Table 3) which were estimated from earlier work by Soulsby et al. (2003). Unsurprisingly the percentage groundwater 

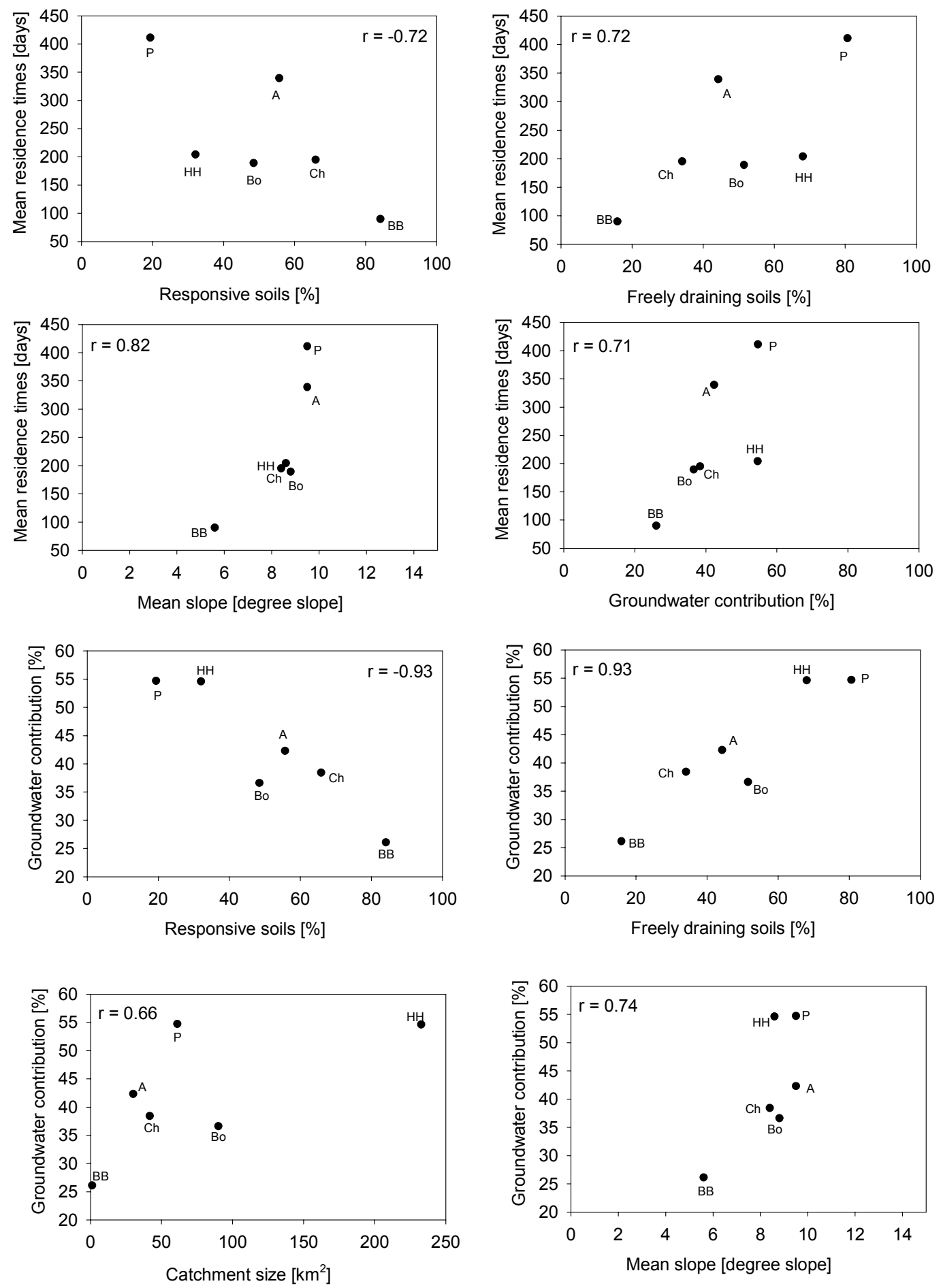

Fig. 7. Selected relationships between catchment characteristics and mean residence time and percentage groundwater contributions to flow.

contribution is also strongly correlated with soil cover and hillslope gradient. Simply stated, higher peat coverage on flatter catchment interfluves results in rapid hydrological responses to precipitation via overland flow or shallow subsurface storm flow, leading to reduced recharge, lower ground- water contributions to baseflows and shorter residence times. Higher coverage of freely draining podzols on steeper hillslopes or alluvium in valley bottom areas increases recharge, produces higher groundwater contributions to annual flow and longer residence times. It appears that landscape 
organisation and the combination of soil/topographic units in different sub-catchments, rather than scale, has the strongest influence on the hydrological characteristics of flow path partitioning and influencing mean residence times in the Feugh catchment. It is also interesting that simple topographic measures (such as mean slope) can be good predictors of mean residence time as topographic maps are readily available for many ungauged basins whereas hydrometric data and soil maps may not be.

\section{Conclusions and implications}

These results contribute to an improved conceptualisation of catchment hydrology for the Feugh, previously based on geochemical tracer analysis (Soulsby et al., 2003, 2004). Variation in stream water $\delta^{18} \mathrm{O}$ is generally consistent with relatively simple two-component mixing, where longer residence time groundwater sustains base flows and more recent, seasonally variable precipitation in surface soil horizons that can be translated to streams as overland flow or shallow subsurface storm flow (usually via macropores) which account for the catchment storm flow response. Over the course of the hydrological year, this mixing process resulted in a reasonably well defined, seasonally evolving isotopic signature that reflects important differences in sub-catchment hydrological processes, and allows intra-catchment differences in stream water residence times to be estimated.

The results provide interesting insights for current understanding on the scaling and integration of hydrological processes in larger catchments. In particular, the results for the largest scale at Heugh Head indicated that the hydrological responsiveness of headwater peat soils (in the Water of Dye) exert the dominant influence on the overall seasonal patterns and residence times observed at the larger catchment scale, despite significant downstream groundwater inputs and mixing with more constant $\delta^{18} \mathrm{O}$ signatures in more groundwater dominated sub-basin drainage. Thus, the results support both theoretical (Haitjema, 1995) and empirical studies (McGuire et al., 2005) that have hypothesized that catchment residence times are not scale dependent. This also displays parallels with recent findings from the similar sized Feshie catchment in the Cairngorm Mountains of Scotland (Rodgers et al., 2005; Soulsby et al., 2004 ${ }^{1}$ ). Residence times in the Feshie ranged from $2-6$ months in catchments dominated by responsive soils, to $12-15$ months in more groundwater dominated catchments with extensive coverage of freely draining soils. Mean residence time at the catchment outfall $\left(230 \mathrm{~km}^{2}\right)$ were 4-7 months, slightly shorter than the Heugh Head in the Feugh catchment. This would appear to be consistent with the higher precipitation levels in the Feshie and the more mountainous terrain (with greater coverage of shallow, responsive alpine soils and bare bedrock).

The results from the Feugh also bear interesting comparison with the findings of other tracer studies; though differ- ent sampling strategies and analytical approaches mean that such comparisons must be cautious. The flashy, responsive nature of the Feugh to rainfall indicates the importance of much shorter residence time waters in the catchment peaty soils in headwaters like Brocky burn. Earlier isotope work in the Allt a' Mharcaidh in the Feshie catchment indicated mean residence times of water in peaty soils were around 2 months (Soulsby et al., 2000). Similarly, others, such as Robson et al. (1992) at Plynlimon in Wales and Nyberg et al. (1999) in Sweden, have used tracer data to imply very short residence times for responsive peaty soils in generating storm runoff. These studies showed that although tracer breakthrough to streams could occur in a matter of minutes or hours, catchment soils still stored significant tracer quantities after a period of a few months.

The importance of groundwater contributions to flow in mountainous environments has increasingly been highlighted in Scotland (e.g. Soulsby et al., 2004) and elsewhere. The results of this study indicate baseflow mean residence times of well over a year for parts of the Feugh catchment. Similarly, Uhlenbrook et al. (2002) showed that shallow and deep groundwater respectively accounted for $69 \%$ and $20 \%$ of annual runoff in $40 \mathrm{~km}^{2}$ Brugga catchment in the Black Forest of Germany. These shallow and deep groundwater sources were each estimated as having mean residence times in the ranges of 2-3 and 5-10 years. Similar residence times have also been estimated in for baseflows, borehole waters or springs in upland environments as different as Plynlimon, Wales (Haria and Shand, 2004); Maimai in New Zealand (McGlynn at al., 2003); pre-Alpine catchments in Switzerland (Vitvar and Balderer, 1997); the Bavarian Alps, Germany (Maloszewski et al., 1983); in Japan (Asano et al., 2002) and the Catskills, USA (Vitvar et al., 2002). Whilst the mean residence times presented in this study do not give direct groundwater residence times, earlier work by Soulsby et al. $(1999,2000)$ in the Cairngorms estimated the mean residence times for shallow and deeper groundwater sources at 2 and 3-5 years respectively. All these studies strongly suggest the presence of long tails in residence time distributions in such mountainous catchments (Kirchner et al., 2000).

Ultimately, it should be stressed that the residence time estimates presented in this study are means and are specific to the study year in question. In reality, catchment runoff is composed of a much wider and more complex range of internal catchment residence time distributions that are currently unknown (Kirchner et al., 2000, 2001). Future work in the Feugh would therefore benefit from direct assessment of different groundwater and soil water stores that are likely to be highly variable (Frederickson and Criss, 1999; Gonfiantini et al., 1998). These could be assessed indirectly through more intensive sampling of stream base flows or possibly using other tracers such as tritium (cf. McGlynn et al., 2003) or CFCs (cf. Uhlenbrook et al., 2002). Moreover, further insights would be gained for improved spatial and temporal resolution of precipitation and stream water samples, which 
is a key objective in future work. Another key objective is to explore more fully the relationship between residence times and catchment characteristics. The analysis presented in this paper is merely a first step as it was limited by the resolution of digital topographic and soil maps available. More detailed and sophisticated analysis is therefore planned which will also be extended to include equivalent chemical and isotope data from other study sites. It is encouraging that simple topographic measures (such as mean slope) can be good predictors of mean residence time and this warrants further investigation. Topographic maps are usually available for ungauged basins whereas hydrometric and isotope data and soil maps may not be.

The results nonetheless highlight the pragmatic utility of stream water oxygen isotope measurements as an analytical tool in the study of mesoscale catchments given that they effectively integrate the influence of these complex catchment heterogeneities as well as indicating the relative importance of different sources in runoff production. This further suggests that the potential of such an approach to improve current understanding of scaling in catchment hydrological processes remains largely underdeveloped (Brown et al., 1999; Genereux and Hooper, 1998; McDonnell et al., 1999, Uhlenbrook et al., 2002). It is important, therefore, that tracer studies such as these are continued in order to refine our understanding of flow paths and residence times, and to help structure and validate more accurate hydrological models.

Acknowledgements. The authors are grateful to the support of NERC through the NERC/JIF CHASM initiative and for supporting PJR on his studentship (GT 4/00/02/). Permission for site access and other support was given by Fasque Estate and the Birse Community Trust. SUERC is funded by a consortium of Scottish Universities and research council support. Alison Sandison and Jenny Johnstone helped with some of the figures. The contributions of DT were funded by the DFG.

Edited by: S. Uhlenbrook

\section{References}

Asano, Y., Uchida, T., and Ohte, N.: Residence times and flow paths of water in steep unchannelled catchments, Tanakami, Japan, J. Hydrol., 261, 173-192, 2002.

Bliss, C. L.: Statistics in Biology, Vol. 2, McGraw Hill, New York, 639pp, 1970.

Boorman, D. B., Hollis, J. M., and Lilly, A.: Hydrology of soil types: a hydrological classification of the soils of the United Kingdom, Inst. of Hydrol., Report 126, Institute of Hydrology, Wallingford, UK, 1995.

Brown, V. A., McDonnell, J. J., Burns, D. and Kendall, C.: The role of event water, rapid shallow flow paths and catchment size in summer storm flow, J. Hydrol., 217, 171-190, 1999.

Burns, D. A.: Stormflow hydrograph separation based on isotopes: the thrill is gone - what's next? Hydrological Processes, 16, 1515-1517, 2002.
Buttle, J. M.: Isotope hydrograph separation and rapid delivery of pre-event water from drainage basins, Progress in Physical Geography, 18, 16-50, 1994.

Buttle, J. M.: Fundamentals of small catchment hydrology, in: Isotope Tracers in Catchment Hydrology, edited by: Kendall, C. and McDonnell, J. J., Elsevier, Amsterdam, 1-43, 1998.

Clark, I. D. and Fritz, P.: Environmental Isotopes in Hydrogeology, CRC Press, 328pp, 1997.

Darling, W. G. and Talbot, J. C.: The O \& H stable isotopic composition of fresh waters in the British Isles. 1. Rainfall, Hydrol. Earth Syst. Sci., 7, 163-181, 2003,

\section{SRef-ID: 1607-7938/hess/2003-7-163.}

Dawson, J. J.: The controls on the concentrations and fluxes of gaseous, dissolved and particulate organic carbon in upland peat dominated catchments, $\mathrm{PhD}$ Thesis, University of Aberdeen, 1999.

DeWalle, D. R., Edwards, P. J., Swistock, B. R., Aravena, R., and Drimmie, R. J.: Seasonal hydrology of three Appalachian forest catchments, Hydrological Processes, 11, 1895-1906, 1997.

Frederickson, G. G. and Criss, R. E.: Isotope hydrology and residence times of the unimpounded Meramec River Basin, Missouri, Chemical Geology, 157, 303-317, 1999.

Genereux, D. P. and Hooper, R. P.: Oxygen and hydrogen isotopes in rainfall-runoff studies, in: Isotope Tracers in Catchment Hydrology, edited by: Kendall, C. and McDonnell, J. J., Elsevier, Amsterdam, 319-346, 1998.

Gonfiantini, R., Frohlich, K., Araguas-Araguas, L., and Rozanski, K.: Isotopes in groundwater hydrology, in: Isotope Tracers in Catchment Hydrology, edited by: Kendall, C. and McDonnell, J. J., Elsevier, Amsterdam, 203-246, 1998.

Haria, A. H. and Shand, P.: Evidence for deep sub-surface flow routing in forested upland Wales: implications for contaminant transport and stream flow generation, Hydrol. Earth Syst. Sci., 8, 334-344, 2004,

\section{SRef-ID: 1607-7938/hess/2004-8-334.}

Healy, J.: Paradigms, policies and prognostications about the management of watershed ecosystems, in: River ecology and management, edited by: Naiman, R. J. and Bilby, R. E., Academic Press, London, 642-661, 2001.

Haitjema, H. M.: On the residence time distribution in idealised groundwatershed, J. Hydrol., 172, 127-146, 1995.

Hill, T. and Neal, C.: Spatial and temporal variation in $\mathrm{pH}$, alkalinity and conductivity in surface runoff and groundwater for the Upper River Severn catchment, Hydrol. Earth Syst. Sci., 1, 697 716, 1997,

\section{SRef-ID: 1607-7938/hess/1997-1-697.}

Jenkins, A., Ferrier, R. C., Harriman, R., and Ogunkoya, Y. O.: A case study in catchment hydrochemistry: conflicting interpretations from hydrological and chemical observations, Hydrological Processes, 8, 335-349, 1994.

Kendall, C. and Coplen, T. B.: Distribution of oxygen-18 and deuterium in river waters across the United States, Hydrological Processes, 15, 1363-1393, 2001.

Kirchner, J. W., Feng, X., and Neal, C.: Fractal stream chemistry and its implications for contaminant transport in catchments, Nature, 403, 524-527, 2000.

Kirchner, J., Feng, X., and Neal, C.: Catchment-scale advection and dispersion as a mechanism for fractal scaling in stream tracer concentrations, J. Hydrol., 254, 82-101, 2001. 
Maloszewski, P., Rauert, W., Stichler, W., and Herrman, A.: Application for flow models in an alpine catchment area using tritium and deuterium data, J. Hydrol., 66, 319-330, 1983.

Maloszewski, P. and Zuber, A.: Determining the turnover time of groundwater systems with the aid of environmental tracers. 1, Models and their applicability, J. Hydrol., 57, 207-231, 1982.

Maloszewski, P. and Zuber, A.: Principles and practice of calibration and validation of mathematical models for the interpretation of environmental tracer data in aquifers, Adv. Water Resour., 16, 173-190, 1993.

McDonnell, J., Rowe, L., and Stewart, M.: A combined tracerhydrometric approach to assess the effect of catchment scale on water flow path, source and age, in: Integrated Methods in Catchment Hydrology - Tracer, Remote Sensing and New Hydrometric Techniques, edited by: Leibundgut, C., McDonnell, J., and Schultz, G. , IAHS Publ. no. 258, 265-274, 1999.

McGlynn, B., McDonnell, J., Stewart, M., and Seibert, J.: On the relationship between catchment scale and stream water mean residence time, Hydrological Processes, 17, 175-181, 2003.

McGuire, K. J., DeWalle, D. R., and Gburek, W. J.: Evaluation of mean residence time in subsurface waters using oxygen-18 fluctuations during drought conditions in the mid-Appalachians, J. Hydrol., 261, 132-149, 2002.

McGuire, K. J., McDonnell, J. J., Weiler, M., Kendall, C., McGlynn, B. L., Welker, J. M., and Seibert, J.: The role of topography on catchment-scale water residence time, Water Resour. Res., 41, W05002, 2005.

Naiman, R. J., Bisson, P. A., Lee, R. G., and Turner, M. G.: Watershed management, in: River Ecology and Management, edited by: Naiman, R. J. and Bilby, R. E., Academic Press, London, 642-661, 2001.

Nyberg, L., Rodhe, A., and Bishop, K.: Water transit times and flow paths from two line injections of ${ }^{3} \mathrm{H}$ and ${ }^{36} \mathrm{Cl}$ in a microcatchment at Gårdsjön, Sweden, Hydological Processes, 13, 15571575, 1999.

Robson, A. J., Beven, K. J., and Neal, C.: Towards identifying sources of subsurface flow: a comparison of components identified by a physically based runoff model and those determined by chemical mixing techniques, Hydrological Processes, 6, 199214, 1992

Rodgers, P., Soulsby, C., and Waldron, S.: Stable isotope tracers as diagnostic tools in upscaling flow path understanding and residence time estimates in a mountainous mesoscale catchment, Hydrological Processes, in press, 2005.

Rodgers, P., Soulsby, C., Petry, J., Malcolm, I., Gibbins, C., and Dunn, S.: Groundwater-surface water interactions in a braided river: a tracer based assessment, Hydrological Processes, 18, 1315-1332, 2004a.

Rodgers, P., Soulsby, C., Petry, J., and Dunn, S.: Integrating tracers and GIS to assess the influence of landscape heterogeneity on runoff processes in a complex mountainous catchment, Proceedings of the BHS International Conference - Hydrology: Science and Practice for the 21st Century, 458-467, 2004b.

Shand, P., Darbyshire, D. P. F., Goody, D. C., Darling, W. G., Neal, C., Haria, A. H., and Dixon, A. J.: The application of Sr isotopes to catchment studies: The Plynlimon upland catchment of Central Wales, Water-rock interaction, Vols. 1 and 2, 1577-1580, 2001.

Sklash, M. G.: Environmental isotope studies of storm and snowmelt runoff generation, in: Process Studies in Hillslope Hydrology, edited by: Anderson, M. G. and Burt, T. P., John Wiley, Chichester, 401-435, 1990.

Sklash, M. G., Farvolden, R. N., and Fritz, P.: A conceptual model of watershed response to rainfall developed through the use of oxygen-18 as a natural tracer, Canadian Journal of Earth Science, 13, 271-283, 1976.

Soulsby C. and Dunn S. M.: Towards integrating tracer studies with a conceptual rainfall-runoff model; insights from a sub-arctic catchment in the Cairngorm Mountains, Scotland, Hydrological Processes, 17, 403-416, 2003.

Soulsby, C., Helliwell, R. C., Ferrier, R. C., Jenkins, A., and Harriman, R.: Seasonal snowpack influence on the hydrology of a sub-arctic catchment in Scotland, J. Hydrol., 192, 17-32, 1997.

Soulsby, C., Chen, M., Ferrier, R. C., Helliwell, R. C., Jenkins, A., and Harriman, R.: Hydrogeochemistry of shallow groundwater in an upland Scottish catchment, Hydrological Processes, 12, 1111-1127, 1998.

Soulsby, C., Malcolm, R., Ferrier, R. C., and Jenkins, A.: Hydrogeochemistry of montane springs and their influence on streams in the Cairngorm Mountains, Scotland, Hydrol. Earth Syst. Sci., 3, 409-419, 1999,

\section{SRef-ID: 1607-7938/hess/1999-3-409.}

Soulsby, C., Malcolm, R., Helliwell, R. C., Ferrier, R. C., and Jenkins, A.: Isotope hydrology of the Allt a' Mharcaidh catchment, Cairngorm mountains, Scotland: implications for hydrological pathways and water residence times, Hydrological Processes, 14, 747-762, 2000.

Soulsby, C., Rodgers, P., Smart, R., Dawson, J., and Dunn, S.: A tracer based assessment of hydrological pathways at different spatial scales in a mesoscale Scottish catchment, Hydrological Processes, 17, 759-777, 2003.

Soulsby C., Rodgers, P., Petry, J., Hannah, D. M., Malcolm, I. A., and Dunn, S. M.: Using tracers to upscale flow path understanding in mesoscale mountainous catchments: two examples from Scotland, J. Hydrol., 291, 174-196, 2004.

Stewart, M. K. and McDonnell, J. J.: Modelling base flow soil water residence times from deuterium concentrations, Water Resour Res., 27, 2681-2693, 1991.

Thompson, D. B. A., Gordon, J. E., and Horsfield, D.: Montane landscapes in Scotland: are these natural artefacts or complex relicts, in: Earth Science and the Natural Heritage, edited by: Gordon, J. E. and Leys, K. F., Stationary Office, London, 105119, 2001.

Turner, J. V. and Barnes, C. J.: Modelling of isotope and hydrogeochemical responses in catchment hydrology, in: Isotope Tracers in Catchment Hydrology, edited by: Kendall, C. and McDonnell, J. J., Elsevier, Amsterdam, 723-760, 1998.

Uhlenbrook, S., Frey, M., Leibundgut, C., and Maloszewski, P.: Hydrograph separations in a mesoscale mountainous basin at event and seasonal timescales, Water Resour. Res., 38, 1096-1110, 2002.

Unnikrishna, P. V., McDonnell, J. J., and Stewart, M. L.: Soil water isotope residence time modelling, in: Solute Modelling in Catchment Systems, edited by: Trudgill, S. T., Wiley, Chichester, 237260, 1995.

Vitvar, T. and Balderer W.: Estimation of mean residence times and runoff generation by stable isotope measurements in a small prealpine catchments, Applied Geochemistry, 12, 787-796, 1997. 
Vitvar, T., Burns, D. A., Lawrence, G. B., McDonnell, J. J., and Wolock, D. M.: Estimation of baseflow residence times in watersheds from the runoff hydrograph recession: method and application in the Neversink watershed, Catskill Mountains, New York, 16, 1871-1877, 2002.

Wade, A. J., Neal, C., Soulsby, C., Smart, R. P., Langan, S. J., and Cresser, M. S.: Modelling streamwater quality under varying hydrological conditions at different spatial scales, J. Hydrol., 217, 266-283, 1999.
Wade, A., Neal, C., Soulsby, C., Smart., R., and Langan, S. J.: On modelling the effects of re-afforestation on acidification in a heterogeneous catchment at different spatial and temporal scales, J. Hydrol., 250, 149-169, 2001. 